\title{
Greening Integration Theory: Normative Basis, Initial
}

\section{Applications}

\section{INTRODUCTION: POLITICAL ECOLOGY FROM ISSUE TO PRISM}

In this article, I set out the contours of a green regional integration theory as a contribution to the more overtly normative research in this field. ${ }^{1}$ Although the EU has been responsible for significant innovation in environmental policy, ecological principles shape neither EU legislation (Burns, Carter and Worsfold 2012) nor its strategic thinking (Warleigh-Lack 2010) on a regular basis. The EU is certainly one of the greenest actors in global politics, but the competition for this title is not particularly stiff; additionally, a recent assessment of the EU's institutional and normative resonance with ecological norms pointed out many weaknesses in this regard (Warleigh-Lack 2014: 5-10). It is thus unsurprising that leading scholars have appealed for greater emphasis on ecological thought as part of the next phase in EU studies and integration theory (Manners 2003; Nicolaïdis 2010).

Other normative perspectives could certainly be useful contributions to the field - for instance, Ian Manners (2007) has called for more critical and feminist approaches, and questions of patriarchy and social equality/justice are compelling issues for analysis. However, I focus on ecological thought for reasons which are both intellectual and practical. On the first count, ecological politics is highly compatible with the pursuit of social justice and feminism; indeed, they are often seen as a core part of ecologists' project of social transformation (Barry 2012). On the second count, my starting point is that ecological principles and problems are the most pressing that we face as a species, since 'if we can't secure our own biophysical survival, then it is game over 
for every other noble aspiration or venal self-interest that we may have' (Porritt 2007: 8).

To take this step, however, is by no means straightforward: greening scholarship calls into question so many established ideas and 'commonsense' understandings of the way the world works, of what and how life is, that it necessarily challenges conceptions of what is a suitable issue for the study and practice of many disciplines, including politics/IR (Wendt and Duvall 2008). Furthermore, existing positive theory approaches in integration theory will retain usefulness, especially in helping analysis of the EU as a political system, but my argument here is that they must be accompanied by more normative approaches whose task is to evaluate, rather than to explain, EU institutions, activity and outputs, and thus drive proposals for change (on the changing phases of integration theory, see O’Neill 2000).

I proceed as follows. First, I set out in more detail the meta-theoretical issues at play in shifting from a conventional understanding of theory and its purposes to a green perspective, presenting Stoker's concept of 'evaluative theory' (Stoker 1995) and matching this to the core epistemological features of a Green approach. Next, I sketch the contours of a Green understanding of politics, drawing particularly on green political theory and Gaia Theory, which has been significant in the greening of IR. To follow this, I set out the kind of regional integration process that would be envisaged from a Green perspective. Finally, I assess the implications for the creation of a 'green' integration theory. 


\section{EVALUATIVE PERSPECTIVES AND THE 'ECOLOGY OF MIND’}

Several contemporary scholars have argued that in order to generate new and useful knowledge it is necessary to move beyond, or at least complement, liberal norms of scholarship as they have tended to pertain in mainstream studies of IR, comparative politics and EU studies (Manners 2007). Such scholars have called for a methodological and epistemological pluralism in which we put our cards on the table and set out our meta-theoretical positions, in order to facilitate self-reflection and intellectual development for the field as a whole (Smith 2007; Wæver 2007).

Gregory Bateson's concept of 'the ecology of mind' is helpful here. From this perspective, it is impossible for humans to observe social phenomena objectively: 'there is much that is our own contribution to our own perception' (Bateson 1991: 222). Furthermore, humans must be understood as part of nature, not separate from it; no-one and nothing is an island, but rather everything exists as part of a circuit or system (Hayward 1995). Thus, human thoughts and action interact with both each other and with other components of the system in which they arise: everything is interconnected, and what we think can shape what comes into existence. From such a premise, it is an easy step to link beliefs with commitment to social transformation: 'Political ecology is... a politics, but it is also an ethics: a moral quest for greater harmony, more autonomy, more solidarity and more responsibility' (Lipietz 1999: 7, my translation).

I defend this move as follows. As an overall justification, it starts from the established point in social science philosophy that the worth of a new theoretical approach can be that it synthesizes aspects of knowledge which were previously separate, generating 
new insights, research or theory as a consequence (Trigg 1991: 110). Revising integration theory as argued for here would draw not only on work in the fields of EU studies, new regionalism and IR more broadly, but also on ecological theory and normative political theory more generally (see Bellamy and Castiglione 2000), thereby reviving the research agenda while refashioning it.

Following on, I maintain that causal theory is ultimately bland if the linkages and processes it uncovers are not linked to some sense of how those lessons can be learned and applied in a normatively progressive manner. This does not mean that empiricism has no place; rather, it means that such work must be treated as a means to an end, and that positivist norms about value-free scholarship and facts which speak for themselves must be challenged (Hovden 1999; Kurki 2006). Regional integration is itself never neutral - it creates winners and losers, and alters balances of power, political opportunity structures and domestic politics generally. It is carried out in the pursuit of goals which are both ideational and material - and as scholars we have a duty to critique these (Kurki and Wight 2007). ${ }^{2}$ In this situation, I maintain our normative duty is to defend/seek the improved welfare of the greatest possible number, within a framework of ecological limits. ${ }^{3}$

Thus, we need an 'evaluative theory' (Stoker 1995: 17) - one which assesses the condition of a phenomenon according to a set of explicit concepts and values. Such approaches posit universally valid values which can be applied based on readily communicable knowledge, but are also non-positivist in the Popperian sense because they place the defence of, and helping progress towards, a set of values and principles as the ultimate value of theory. This can of course lead to a clash of norms between 
scholars and even between scholars and practitioners - but such is the stuff of both politics and intellectual life.

From a Green perspective, an evaluative approach is eminently suitable. Ecological thought (see below) overtly challenges the idea that scholarship should be devoid of social criticism (Hayward 1995; Lipietz 1999), considering ethical and philosophical questions to be central to academic enquiry. Indeed, for Green thinkers, the very purpose of scholarship is 'changing the world through (changing) the way people

think...and the inculcation of new kinds of ecological sensibility' (Dryzek 2005: 183). For Ian Manners (2003: 80), this requires a radical interdisciplinarity, and a location of the study of any given region in its 'social and political context', a process which also challenges the idea of anthropocentrism and thus extends 'the project of emancipation to include both the human and the nonhuman world' (Eckersley 2004: 9). It is to an investigation of how that might be done - and thus to Green political theory - that I now turn.

\section{GREEN THEORY AND POLITICS - A BRIEF ECOLOGIST PERSPECTIVE ${ }^{4}$}

An initial observation on Green political theory is that, in common with many nonmainstream perspectives, it is not a uniform school (see Carter 2001; Dryzek 2005). There are many strands of thought ranging from the cautious to the radical, and various schemes to classify a range of perspectives along that spectrum. One helpful way of navigating this diversity has been put forward by Andrew Dobson (2000: 2); he posits a typology that ranges from 'environmentalism' to 'ecologism', with the former understood as 'a managerial approach to environmental problems, secure in the belief that they can be solved without fundamental changes in present values or 
patterns of production and consumption', while the latter is considered as the belief that 'a sustainable and fulfilling existence presupposes radical changes in our relationship with the non-human natural world, and in our mode of social and political life'.

However, even at the ecologist end of the spectrum, diversity persists. For instance, some thinkers consider the path of 'sustainable development' to be the way forward, one that is in its implications so radical that it could transform capitalism and hence society (Barry 1999; Carter 2001). ${ }^{5}$ Others argue that the emphasis it contains on economic development rules it out as a truly ecological perspective (for discussion, see Dryzek 2005: 159-60), while others point to how powerful forces in society have deliberately neutered more radical interpretations of this idea, presenting unsustainable practices as ecologically sound and 'bolstering the argument that radical system change is not actually required as environmental goals can be realised through the modification of existing structures' (Blühdorn and Welsh 2007: 194). ${ }^{6}$ Disciplines such as philosophy, chemistry, microbiology and theology have contributed to ecologism, and scholars of politics and economics have both contributed to this nexus and responded to it. Thus, the perspective set out here cannot be a definitive account of ecologist principles: rather, it is one informed by them. It begins with the norms outlined by the originator of the Deep Ecology movement, the philosopher Arne Næss, as set out in Table $1 .^{7}$ 
Central to ecologist beliefs is a rejection of anthropocentrism - the idea that humans are the source of all value and that humans should be predominantly concerned with their own species' interests (Carter 2001: 14). Instead, anthropocentrism is considered to be not only mistaken but historically unusual - the product of a particular historical context and mode of thinking which has been falsely projected as universal (Hovden 1999), and which is by no means as apparent in other cultures and times as in the post-Enlightenment West (Shiva 1989). For ecologists, humankind is to be conceived as part of a much broader and interdependent system of life on the planet, often but not exclusively referred to as Gaia (Leopold 1968 [1949]; Litfin 2004; Lovelock 2009). Indeed, humankind should properly be understood as 'one of the partner species in the great enterprise of Gaia' (Lovelock 2009: 6; Margulis 1998).

This in turn generates a view of human nature as something which is capable of adaptation and transformation rather than somehow fixed, and one which at base is much more in tune with symbiosis and cooperation than with competition (Margulis 1998). Ecologism is also non-dualist in its orientation (Hayward 1995); although several ecologists from a natural science background (such as Lynn Margulis) are cautious about what they consider the sometimes unscientific uses of their work by ecologists in other disciplines, most ecologists argue that only by reuniting (social) science with ethics and philosophy are we likely to be able to respond successfully to the real-world challenges of ecological degradation (Capra 1997; Hardin 2007; Midgley 2001).

For ecologists, then, political and social life requires a radical overhaul. Although local economies and communities are given centrality on the grounds of self- 
determination and local democracy, as well as to limit resource use, this must be seen in the context of a moral and ethical universalism in which a national border is considered to be 'not a wall but a very permeable membrane indeed' (Thompson 1987: 169). In this view, moral duties to fellow humans and other species are paramount regardless of their physical location. As Drengson and Devall (2008) put it, there are also clear limits to the desirability of local autonomy; local communities may fail to respect human rights, for example. Thus, in order to resolve intercommunity (or inter-national) disputes, or to guarantee rights provision, central authorities will be required (Eckersley 2004). Moreover, in ecological politics, developed nations have a strong obligation to citizens of the so-called developing countries; to ensure all humans have a suitable standard of living and quality of life, citizens of the global North will have to give up some of their wealth in a global redistribution process which enables the South to live comfortably while avoiding the industrial path to material prosperity (Kelly 1994).

\section{GREENING INTEGRATION: WHAT KIND OF INTEGRATION, AND FOR}

\section{WHAT PURPOSE?}

Thinking about what a green regional integration process would look like is at an early stage, as is Green thought regarding the role of regional integration in the broader global context. In considering these issues here, and in the next section too, I have generally drawn on ecologist scholars rather than those of regional integration per se, and frequently inferred or extrapolated from their work. ${ }^{8}$ 
However, it is still necessary to provide an understanding of 'regional integration' in order to assess what kind of process would be desired from an ecologist perspective. Here, there is more leeway than might be expected: revisionist neofunctionalists themselves set aside Haas' (2004 [1958]: 16) original definition - 'the process whereby political actors in several distinct national settings are persuaded to shift their loyalties, expectations and political activities towards a new centre, whose institutions possess or demand jurisdiction over the pre-existing national states' - as part of their reworking of that theory (Haas 2001: 24). Furthermore, recent scholarship indicates that it is idle to expect a tight, fully transferable definition of regional integration, especially given an academic context in which the term 'integration' can be rejected by scholars of regions other than the EU as hopelessly Eurocentric: '(1)abelling a process as regional integration rather than as cooperation is always done in a specific discursive context' (Van Langenhove 2011: 96). There are varieties of 'region-ness' observable in the real world (Hettne 2002), and a focus on defining regional integration through what it does, how it works, and the outcomes it generates - its projects, processes and products - may be the most suitable approach to take (Warleigh-Lack and Van Langenhove 2010; Van Langenhove 2011). Such a posture would certainly be in keeping with ecologist thought, in which respect for diversity is a core strand (Litfin 2004).

A green perspective thus understands regional integration as, at least potentially, a normatively desirable phenomenon, provided certain conditions are met. An integration process which contributes to the process of ecological degradation or makes this harder to address would of course be rejected, and many ecologists share with anarchists a principled opposition to organised governance beyond the most 
basic level (for a discussion, see Eckersley 2004: 139-69). However, many ecologists do perceive value in regional integration as a means to an end - if it helps bring peace, promotes a sustainable economy and increases social justice, then it is to be welcomed, especially as a bulwark against globalisation forces which might otherwise pull actors in a different and more neoliberal direction (Woodin and Lucas 2004). There is no automatic respect for the Westphalian nation-state as a model of political economic and social life in ecologist thought: it is at once both too small and too large to be effective in the context of Gaia, and indeed can be read as the very emblem of how Western understandings of the 'good life' and political organisation have gone awry (Deudney 1998; Litfin 2003). Thus, regional integration might be considered a source of 'best practice' in terms of how far real-world politicians have been able to approximate ecologist ideas and ideals of governance as a kind of 'via media' between localism, national sovereignty and global governance - for instance, the EU has been seen in this regard (Eckersley 2004: 251; Lipietz 1995).

Hence, and to use an everyday phrase, the proof of the pudding is in the eating. Regional integration is most appropriately conceived as, at its best, an emergent system which by definition adds to the value of its parts, such as member states, substate regions, and citizens, making them more effective and better-placed to respond to difficult policy challenges in a context of shared political space (Capra 1997; Lipietz 1995). In a context of global ecological crisis, recovery requires solidarity across borders; climate change cannot be mitigated, or adapted to, solely inside nation-states (Litfin 2004). Moreover, ecological security - the ongoing existence of a life-supporting planetary system in which humans and other species can flourish - is promoted by green thinkers as the most fundamental and necessary form of security 
(Shiva 2005). This requires effective governance, and there is no a priori reason why regional integration cannot be useful in this regard. Indeed, in keeping with the fact that ecosystem management 'challenges the principal dimensions of state sovereignty: autonomy, control and authority' (Ward 1998), there is a need for structures at a level beyond the national, but below the global, to ensure that ecological systems are maintained in good health. ${ }^{9}$

That said, ecologists would desire regional integration to espouse values and practices which are at best only partially evident in existing regional integration processes. As advocates of positive liberty (de Shalit 1997), ecologists would expect and want regional integration to go beyond models of the regulatory state, 'actively intervening in society and the economy in order to promote social and environmental justice' (Eckersley 2004: 161). To some extent, then, regional integration can for ecologists be legitimised on the basis that it helps produce more and better public goods - albeit at the price of rethinking what we mean by that concept in turn, to focus more clearly on less materialistic modes of human flourishing (Jackson 2009). Such an approach would require a shift in political economy away from neoliberalism and towards a very different understanding of how socio-economic life should be organised, as signalled above (Cato 2013). This, of course, has major implications for a range of policy areas at regional level: the European Union's agricultural policy, environmental policy in the North American Free Trade Agreement (NAFTA) area, and the attitude of ASEAN (Association of South-East Asian Nations) towards human rights abuses in its member states, to name but three, would all require radical changes. 
Regional integration can be envisaged as a means whereby governance can be based on non-hierarchical, polycentric, network-based structures and processes, drawing fundamentally on logics of cooperation rather than competition (Madron and Jopling 1993). On a range of policy issues, regional integration can generate more, and more helpful, outcomes than any state, part of a state, or citizen could hope to achieve either unilaterally or at another level of governance (Woodin and Lucas 2004: 213). However, integration would need to be considered as an open process, not a closed project of building an impermeable regional entity: regions would ultimately have to be part of a global system of governance, seeking to shape it in ecologist ways, rather than constituting a barrier to such a global level of governance whose creation would ultimately reflect our global interconnectedness as part of a planetary ecosystem (Deudney 1998; Litfin 2004).

Decision-making in regional integration would also need to be reconsidered if it is to match ecologist thinking. Participatory and deliberative forms of democracy are advocated by ecologists (Madron and Jopling 2003; Dryzek 2005), and thus reform away from intergovernmentalism, bargaining and even representation as per the conventional liberal democratic model may be required, at least at certain levels of the multi-level regions envisaged in ecologist perspectives. In order to take in the full range of 'stakeholders' in a decision - non-human animals, future generations etc ecologists also advocate forms of role-play and reforms of representation, so that those likely to be affected by policy choices, but who are not adult humans possessing the right to vote, are included, even by proxy, in deliberation and decision processes (Ball 2006; Dobson 2010; Read 2012). ${ }^{10}$ This is, to put it mildly, a radical step, but it would have to be taken for regional integration to approximate ecologist 
understandings of democracy and mutuality. Having sketched the contours of an ecologist regional integration process, I turn in what follows to the implications of such understandings for the development of integration theory.

\section{CONCLUSIONS: GREENING INTEGRATION THEORY - NEW NORMS,}

\section{DIFFERENT PROJECTS}

A Green integration theory, as will be clear, is one of a different kind from those to which we are accustomed. Its focus is evaluative and on understanding phenomena, rather than on explaining or predicting them - although green norms could certainly be used to generate convincing explanations of phenomena such as the persistence of neoliberalism after the 2008 financial crisis (Barry 2012). Furthermore, and as discussed above, a Green integration theory would be holistic, using a systems-based epistemology.

The added value of such an approach comes from its contribution to, and extension of, the 'normative turn' in integration theory, which has focused primarily on questions of legitimacy, democracy and public-space, or even demos, construction (Chryssochoou 2009: 105-30). A green integration theory is not focused primarily on understanding the reasons why states choose to integrate, or on explaining how the EU system makes policy. Existing approaches, whose projects fit such matters more closely, will continue to be useful. Indeed, they will be necessary, since without an accurate, empirically-based understanding of the multi-level politics of compromise and contestation that shape EU outcomes, more normative approaches will float without anchor. 
TALK ABOUT ADDED VALUE HERE - DIMITRIS, POTENTIAL FOR

CONTINUED USE OF APPROACHES SUCH AS

EUROPEANISATION/GOVERNANCE/POLICY NETWORKS

Greening integration theory, then, requires a mixture of prescriptive and analytical work. Drengson and Devall's (2008: 173-80) understanding of Næss' (1989) Deep Ecology approach serves as the exemplar here; according to this perspective, scholars must derive norms and hypotheses from core Deep Ecology principles (see Table 1), but must also be prepared to revise those principles if required by evidence and be ready to apply them in a way which is sensitive to context. In other words, different regional integration processes may need to be understood or evaluated using different versions of the theory at a given stage in their existence, or because of their component states. What counts, then, is the application of the core principles, rather than the elaboration of a single, parsimonious model. Table 2 sets out some of the key aspects of ecologist work and how they might be translated into dependent variables for integration theory.

\section{TABLE 2 ABOUT HERE}

Based on this mixture of prescription and analysis, green integration theories must also be open to action research, focused on bridging the academic-practitioner gap. There is no point generating insights into how regional integration processes work or stall in the transition to a sustainable way of living if such insights cannot be translated into policy recommendations or prescriptions for behaviour change. ${ }^{11}$ 
As part of the normative stance taken by adopting a green perspective, it is necessary to break with ideological attachment to the Westphalian nation-state, instead critiquing it as past its sell-by date both normatively and practically (Litfin 2003). States are likely to have their place as part of a multiple layer system of governance networks (Eckersley 2004), but they are not to be considered the ultimate form of political organisation from a normative point of view (as in neorealism) or the essentially unchanging, if domestically contested, ultimate expression of political power (as in liberal intergovernmentalism).

Furthermore, a core task in green integration theory is to re-think understandings of community and loyalty beyond the nation state, to use a familiar term. This is an old theme in integration theory, of course, going back to early neofunctionalism - albeit in a rather thin form (Bellamy and Warleigh 1998). However, a green approach here would be based on a clear and strong normative component rather than the mutual satisfaction of sectoral (policy issue) interests as in neofunctionalism: perhaps an ethics of shared responsibility, undertaken to incorporate 'obligations to the human species, the non-human species and the environment' (Linklater 2006: 111), or a shared morality (McLaughlin 1995) should serve as the basis of this new sense of community; in either case, though, it would also be based on multiple rather than impermeable layers of identity, ranging from the local to the global (Barry 1999).

The more policy- or polity-analytical focus of green integration theory would start from the observation that the pursuit of social and ecological justice is required by symbiosis (our existence as part of the broader planetary eco-system), but also that given the point at which such work must start - i.e. how things stand today - this is 
unlikely to be achieved without struggle and/or suasion (Litfin 2004). Lions do not usually just lie down with lambs after all. It is here that green thinking has two distinctive elements to add to integration theory. First, it offers an opportunity to rethink what we consider by the term 'self-interest'; if we understand ourselves as part of a planetary symbiosis, then the interest of the Other becomes ultimately identical to our own - there is no meaningful separation between 'us' and 'them' if we are all part of the same system, since we are therefore all interdependent (Margulis 1998; Litfin 2004). Second, it allows scholars to focus on issues of polity- and policy-design, conjuring up (achievable) visions of how integration processes can contribute to more pleasant ways of living in order to inspire change, but also to generate support for and engagement with regional integration - which notoriously suffers from legitimacy deficits not only in Europe but also elsewhere. ${ }^{12}$ As John Barry (1999: 107) puts it: 'Green politics in the last analysis is not simply about macro-level changes, but is also about choosing to live in a different manner at the micro-level of individuals and communities...individuals are faced not just with the question of "What ought I to do?" but, more importantly have to ask themselves "What sort of person do I wish to be?", and ultimately "What sort of society do I wish to live in?"”

Second, ecologist thought shows us that we need to focus on power analysis - who has it, where and how is it used, and to what effect (Næss 1989: 130-1), while adding a new dimension to such work. This is a focus which is surprisingly rare in the English-language mainstream in EU studies (Belot, Magnette and Saurugger 2008), but less so in the scholarship on other regions, where critical and political economy work is more frequent (Söderbaum and Shaw 2003). From a specifically green perspective, however, a different range of questions from those in most political 
economy needs to be asked. These would include issues such as the following: what counts as a 'resource'? What counts as a 'cost'? How, if at all, can we put a monetary value on environmental goods, and environmental bads? How can we re-regulate markets, empowering local economies so that they are as autonomous and self-reliant as possible while linking them in to a global, sustainable fair-trade economy (Barry 1999; Cato 2013; Woodin and Lucas 2004)?

Third, how can regional integration contribute to the holistic management of ecosystems, as part of an open, multi-level governance system (Ward 1998), by fostering suitable degrees of trust and perception of long-term shared interests across borders in order to establish suitable governance mechanisms? How should such regions relate to each other to manage inter-regional ecosystem issues? What kind of external policy actor, in fact, should such regions be?

Rethinking democratic governance is a related and perhaps concluding project for the early stages of greening integration theory. In addition to transforming general understandings of community and loyalty, green regional integration processes will need to incorporate structures and processes of decision-making which go beyond contemporary structures in several ways.

First, intergovernmental processes - such as those in ASEAN, NAFTA or the European Council - are not sufficient to provide legitimacy, because they rely on nationally-delimited sources of power, short-term thinking and elite-level bargaining rather than multi-level deliberation and participatory democracy. Research into how these processes could be transformed or complemented, perhaps drawing on the 
literature on EU democracy as one set of ideas to draw on and critique, is thus worthwhile. ${ }^{13}$ Second, experiments with intergenerational solidarity (including the asyet unborn), as well as links across the species barrier, will be necessary in rethinking democracy in regional integration, as at any other level of governance. When ASEAN decides on its environmental policy, for instance, how many generations into the future do its elites stretch their imaginations to weigh up benefits and costs of a policy choice? How far should they extend? When the EU decides upon energy security - as it increasingly does - do, for example, the implications of nuclear waste disposal for future generations weigh at least equally with perceived economic costs of investing in renewable energy, or geopolitical calculations regarding natural gas supplies? To take another example: doesn't NAFTA have a moral duty to improve animal welfare? If not, why, given that regional integration in North America has an impact - adverse in some cases - on its non-human but sentient population, as well as its human equivalent? ${ }^{14}$

Some of these projects may seem outlandish at first, and this is because they require a paradigm shift. Regional integration scholars are not used to thinking of cats, bacteria or indeed the planet as political subjects. ${ }^{15}$ There are, however, precursors in both integration theory and IR work more generally on which to draw when recasting regional integration studies in a green manner. David Mitrany, for instance, long ago heralded the idea of regions as part of, not a barrier to, an evolving, norm-driven world system of governance (Mitrany 1944). Luk Van Langenhove has shown how the study of regions across the globe can be undertaken normatively (Van Langenhove 2004). Political theorists have contributed very heavily to the re-thinking of EU democracy (e.g. Eriksen and Fossum 2000). Multi-level governance scholars 
have pointed to the EU as novel, polycentric and evolving polity, and applied their thinking to entities outside Europe (Hooghe and Marks 2001).

This is not to imply that such work is automatically compatible with ecologism; it simply, but promisingly, means that scholars attempting to green integration theory do not have to start in a vacuum, or draw solely on ecologist literature: greening integration theory could be a fruitful place for collaboration between ecologist scholars and those of the EU and other regions, of benefit to the former in helping them apply their principles effectively, and to the latter by helping them contribute to a new and larger range of debates. Such would be in keeping with the need for (European) integration theory to refresh itself and investigate new ideas (Wiener and Diez 2009).

Word count, including references, footnotes and tables: 7,874 


\section{NOTES}

${ }^{1}$ The article does not, therefore, address the work of Green parties in EU/European politics, or EU environmental policy per se. There are excellent literatures on both; on the former, see inter alia Bomberg 1998 and Burchell 2002; on the latter, see inter alia Wurzel and Connelly 2011, and Jordan and Abelle 2012.

${ }^{2}$ I acknowledge that a generally applicable theory of or approach to regional integration cannot and must not draw only on material from EU studies, or on the EU as the sole model or source of evidence. It must by definition be applicable to, and draw lessons from, regional integration processes wherever they take place. This requires scholars to draw on insights from new regionalism studies as well as those of the EU, and such open-ness is particularly helpful in an evaluative reorientation of integration theory given the range of more critical voices to be heard in scholarship on and of regions other than the EU. See Söderbaum 2009.

${ }^{3}$ Witness the close linkages between neofunctionalism, the 'Community Method' and arguments in favour of European integration, or the 'ASEAN Way' and variants of new regionalist work.

${ }^{4}$ On the universal application of such moral principles, see Singer 2004. It may be fashionable or politically expedient to speak of cultural difference and allow human rights to differ on that basis - but it is not normatively acceptable to do so, as might be attested by gay men about to be stoned to death in Iran because of their sexual orientation or forcibly-circumcised women in Sudan. 
${ }^{5}$ Throughout the rest of this article, I use 'ecologist' and 'green' as synonyms.

${ }^{6}$ Sustainable development is the notion that economic, social and environmental objectives can be achieved simultaneously, albeit through a process of trade-offs and balances. It can be defined as follows: 'Humanity has the ability to make development sustainable - to ensure that it meets the needs of the present without compromising the ability of future generations to meet their own needs' (WCED 1987: 8).

${ }^{7}$ The concept of 'ecosystem services' is illustrative. For some ecologists, the idea that a price can be put on the ways in which we as a species are dependent upon the environment for our economic activity represents a way in which Green thinking can be made intelligible to those within the mainstream by speaking the language of rational choice and cost-benefit calculations (Porritt 2007: 156). However, for other ecologists this is a fundamentally flawed way of understanding the core issue: "the new economics has always been sceptical of the idea of pricing the environment to make it friendlier to old economics rather than re-thinking economics so that it is friendlier to the environment' (Boyle and Simms 2009: 98-9).

${ }^{8} \mathrm{Næss}$ ' approach emphasised ongoing reflexivity and a dynamic approach to the principles he set out; this was, in fact, a core part of what he called 'ecosophy', or the basis of turning philosophical values and beliefs into practical political action (Næss 1989). 
${ }^{9}$ For a different set of thoughts on the ethical purposes and value of regional integration, with particular reference to the individualism/collectivism dichotomy, see Van Langenhove 2004.

${ }^{10}$ In green theory, the concept of the 'bioregion' - a geographically delimited ecosystem - is instructive here. Bioregions are considered to be core focal points for sound governance, since they provide natural 'borders' between communities, and thus help those communities determine what living in tune with Gaia would mean in their particular geographical context. However, bioregions are controversial within Green thought, since they are grounded in an extremely strong form of communitarianism which can lapse into autarky (Barry 1999). There is also no guarantee that bioregions and ecosystems map across successfully to existing regional integration schemes - such schemes are just as likely to be arbitrary functions of human decision-making as nation states. However, if bioregions are seen as nesting one inside another, like so many Russian dolls, ranging in scale from the very local to the global bioregion of the planet itself, there is scope for their inclusion in IR theory in general and integration theory in particular. See Dobson 2000.

${ }^{11}$ The classic notion here is ‘thinking like a mountain' - see Leopold 1968.

${ }^{12}$ On the need for this kind of epistemology in the social sciences more generally, i.e. not from a specifically ecologist perspective, see Van Langenhove 2007.

${ }^{13}$ On democracy and regional integration beyond Europe, see the essays in Anderson 1999. 
${ }^{14}$ On the scope for and mutual benefits of exchange, comparison and learning between scholars of EU studies and those of other regionalisms, see the essays in Warleigh-Lack, Robinson and Rosamond 2011.

${ }^{15}$ On animal rights and interests, see the essays in Sunstein and Nussbaum 2004.

16 By 'political subjects' I here mean entities with at least potential agentic capacity, not 'political questions/issues'. One of the key contributions of ecological political thought is to demonstrate that non-human creatures, and even inorganic matter, can have such capacity, either as an individual embedded in the 'dense network of relations' that constitutes the living world (Bennett 2010: 13), or as a tiny part of that system itself (Margulis 1998: 126). 


\section{REFERENCES}

Andersen, J (ed) (1999): Regional Integration and Democracy: Expanding on the European Experience Lanham: Rowman and Littlefield

Ball, T (2006): ‘Democracy'. In A Dobson and R Eckersley (eds) Political Theory and the Ecological Challenge Cambridge: Cambridge University Press, pp 131-47.

Barry, J (1999): Rethinking Green Politics: Nature, Virtue and Progress London: Sage.

Barry, J (2012): The Politics of Actually Existing Unsustainability: Human Flourishing in a Climate-Changed, Carbon-Constrained World Oxford: Oxford University Press

Bateson, G (1991): A Sacred Unity: Further Steps to an Ecology of Mind New York: HarperCollins

Bellamy, R and Warleigh, A (1998): 'From and Ethics of Integration to an Ethics of Participation: Citizenship and the Future of the European Union', Millennium 27:3, $447-70$

Bellamy, R and Castiglione, D (2000): 'Legitimizing the Euro-"Polity" and its “Regime" - The Normative Turn in EU Studies', European Journal of Political Theory 2:1, 7-34 
Belot, C, Magnette, P and Saurugger, S (eds) (2008): Science politique de l'Union Européenne Paris: Economica

Bennett, J (2010): Vibrant Matter : A Political Ecology of Things Durham, NC: Duke University Press

Blühdorn, I and Welsh, I (2007): 'Ecopolitics Beyond the Paradigm of Sustainability: A Conceptual Framework and Research Agenda'. Environmental Politics 16: 2, 185205.

Bomberg, E (1998): Green Parties and Politics in the European Union London: Routledge

Boyle, D. \& Simms, A. (2009): The New Economics: A Bigger Picture (London: Earthscan)

Burchell, J (2002): The Evolution of Green Politics: Development and Change Within European Green Parties London: Earthscan

Burns, C, Carter, N and Worsfold, N (2012): 'Enlargement and the Environment: The Changing Behaviour of the European Parliament', Journal of Common Market Studies 50:1, 54-70

Capra, F (1997): The Web of Life: A New Synthesis of Mind and Matter London: Flamingo. 
Carter, N (2001): The Politics of the Environment: Ideas, Activism, Policy Cambridge: Cambridge University Press

Cato, M S (2013): The Bioregional Economy: Land, Liberty and the Pursuit of Happiness London: Earthscan

Chryssochoou, D (2009): Theorizing European Integration ( $2^{\text {nd }}$ ed) London: Routledge

De-Shalit, A (1997): 'Is Liberalism Environment-friendly?', in R Gottlieb (ed) The Ecological Community: Environmental Challenges for Philosophy, Politics and Morality London: Routledge, pp 82-103

Deudney, D (1998): 'Global Village Sovereignty: Intergenerational Sovereign Politics, Federal-Republican Earth Constitutions and Planetary Identities', in K Litfin (ed) The Greening of Sovereignty in World Politics Cambridge, MA: MIT Press 299325.

Dobson, A (2010): 'Democracy and Nature: Speaking and Listening'. Political Studies 58:4, 752-68

Dobson, A. (2000): Green Political Thought, $3^{\text {rd }}$ ed. London: Routledge. Dominguez R, E 
Drengson, A and Devall, B (eds) (2008): The Ecology of Wisdom: Writings by Arne Nass Berkeley, CA: Counterpoint.

Dryzek, J (2005): The Politics of the Earth: Environmental Discourses Oxford: Oxford University Press

Eckersley, R (2004): The Green State: Rethinking Democracy and Sovereignty Cambridge, MA: MIT Press

Eriksen, E and Fossum, J (eds) (2000): Democracy in the European Union: Integration Through Deliberation? London: Routledge

Haas, E (2001): 'Does Constructivism Subsume Neofunctionalism?', in T Christiansen, K-E Jørgensen and A Wiener (eds) The Social Construction of Europe London: Sage, pp 22-31

Haas, E (2004[1958]): The Uniting of Europe: Political, Social and Economic Forces, 195-1957 Notre Dame: University of Notre Dame Press

Harding, S (2007): ‘Animate Earth', in M Migley (ed) Earthy Realism: The Meaning of Gaia, pp 23-9

Hayward, T (1995): Ecological Thought: An Introduction Cambridge: Polity 
Hettne, B (2002): 'The Europeanisation of Europe: Endogenous and Exogenous Dimensions', Journal of European Integration 24:4, 325-40

Hollis, M and Smith, S (1991): Explaining and Understanding International Relations Oxford: Clarendon

Hooghe, L and Marks, G (2001): Multi-level Governance and European Integration Lanham: Rowman and Littlefield

Hovden, E. (1999): ‘As if Nature Doesn't Matter: Ecology, Regime Theory and International Relations', Environmental Politics 8:2, 50-74

Jackson, T. (2009): Prosperity Without Growth: Economics for a Finite Planet London: Earthscan

Jordan, A and Adelle, C (eds) (2012): Environmental Policy in the European Union: Actors, Institutions and Processes ( $3^{\text {rd }}$ ed) London: Routledge

Kelly, P. (1994): Thinking Green: Essays on Environmentalism, Feminism and Nonviolence (Berkeley, CA: Parallax Press)

Kuhn, T (1977): The Essential Tension: Selected Studies in Scientific Tradition and Change Chicago: University of Chicago Press 
Kurki, M (2006): 'Causes of a Divided Discipline: Rethinking the Concept of Cause in International Relations Theory', Review of International Studies 32, 189-216

Kurki, M and Wight, M (2007): 'International Relations and Social Science'. In T Dunne, M Kurki and S Smith (eds) International Relations Theories: Discipline and Diversity Oxford: Oxford University Press, pp. 13-33

Laferrière, E. \& Stoett, P. (1999): International Relations Theory and Ecological Thought: Towards a Synthesis London: Routledge

Leopold, A (1968 [1949]): A Sand County Almanac, and Sketches Here and There Oxford: Oxford University Press

Linklater, A (2006): ‘Cosmopolitanism'. In A Dobson and R Eckersley (eds) Political Theory and the Ecological Challenge Cambridge: Cambridge University Press, pp $109-27$.

Lipietz, A (1995): Green Hopes: The Future of Political Ecology Cambridge: Polity Lipietz, A (1999): Qu'est-ce que l'écologie politique? La Grande Transformation du XXIème Siècle Paris: La Découverte

Litfin, K (2003): ‘Towards an Integral Perspective on World Politics: Secularism, Sovereignty and the Challenge of Political Ecology', Millennium: Journal of International Relations 32:1, 29-56. 
Litfin, K (2004): 'Gaia Theory: Intimations for Global Environmental Politics', in P. Dauvergne (ed) International Handbook of Environmental Politics Aldershot: Edward Elgar, pp 502-17.

Lovelock, J (2009): The Vanishing Face of Gaia: A Final Warning London: Penguin.

Madron, R and Jopling, J (2003): Gaian Democracies: Redefining Globalisation and People Power Totnes: Green Books

Manners, I (2003): 'Europaian Studies’, Journal of Contemporary European Studies $11: 1,67-83$

Manners, I. (2007): Another Europe is Possible: Critical Perspectives on European Union Politics, K. E. Jørgensen, M. Pollack and B. Rosamond (Eds.) Handbook of European Union Politics , pp.77 - 95

Margulis, L (1998): Symbiotic Planet: A New Look at Evolution New York: Basic Books.

McLaughlin, A (1995): ‘For a Radical Ecocentrism'. In A Drengson and Y Inoue (eds) The Deep Ecology Movement: An Introductory Anthology Berkeley, CA: North Atlantic Books, pp 257-80.

Midgley, M (2001) Gaia: The Next Big Idea London: Demos 
Mitrany, D (1944): A Working Peace System London: Royal Institute of International Affairs

Mjøset, L (1999): 'Understanding of Theory in Social Science', ARENA Working Paper 99/33

Næss, A (1989): Ecology, Community and Lifestyle: Outline of an Ecosophy Cambridge: Cambridge University Press.

Nicolaïdis, K (2010): 'The JCMS Annual Review Lecture - Sustainable Integration: Towards EU 2.0?', Journal of Common Market Studies 48 (Annual Review), 21-54

O’Neill, M (2000): 'Theorising the European Union: Towards a Post-Foundational Discourse', Current Politics and Economics of Europe 9:2, 121-45

Porritt, J (2007): Capitalism as If the World Matters London: Earthscan

Read, R (2012): Guardians of The Future: A Constitutional Case for Representing and Protecting Future People Weymouth: Green House (online at www.greenhousethinktank.org)

Shiva, V (1989): Staying Alive: Women, Ecology and Development London: Zed Books. 
Shiva, V. (2005): Earth Democracy: Justice, Sustainability and Peace London: Zed

Singer, P (2004): One World: The Ethics of Globalization, $2^{\text {nd }}$ ed. New Haven: Yale University Press.

Smith, S (2007): 'Introduction: Diversity and Disciplinarity in International Relations Theory', in T Dunne, M Kurki and S Smith (eds) International Relations Theories: Discipline and Diversity, Oxford: Oxford University Press, 1-12

Söderbaum, F (2009): ‘Comparative Regional Integration and Regionalism', in T Landman and N Robinson (eds) The Sage Handbook of Comparative Politics London: Sage, 477-96

Stoker, G (1995): 'Introduction', in D Marsh and G Stoker (eds) Theory and Methods in Political Science Basingstoke: Macmillan

Sunstein, S and Nussbaum, M (eds) (2004): Animal Rights: Current Debates and New Directions. Oxford: Oxford University Press.

Thompson, W. I. (1987): 'Gaia and the Politics of Life'. In W.I. Thompson (ed) Gaia: A Way of Knowing Great Barrington, MA: Lindisfarne Press, pp 167-214

Trigg, R (1991): Understanding Social Science: A Philosophical Introduction to the Social Sciences Oxford: Blackwell 
Van Langenhove, L (2004): 'Regional Integration and the Individualism/Collectivism Dichotomy', Asia Europe Journal 2, 95-107

Van Langenhove, L (2007): Innovating the Social Sciences Vienna: Passagen

Van Langenhove, L (2011): Building Regions: The Regionalization of the World Order Aldershot: Ashgate

Wæver, O (2007): ‘Still a Discipline After All These Debates?', in T Dunne, M Kurki and S Smith (eds) International Relations Theories: Discipline and Diversity, Oxford: Oxford University Press,288-308

Ward, V. (1998): 'Sovereignty and Ecosystem Management: Clash of Concepts and Boundaries?', in K Litfin (ed) The Greening of Sovereignty in World Politics Cambridge, MA: MIT Press, 79-108

Warleigh-Lack, A (2010): 'Greening the European Union for Legitimacy? A Cautionary Reading of Europe 2020', Innovation: The European Journal of Social Science, 23:4, 2010, 297-321.

Warleigh-Lack, A (2014): Greening the European Union London: GreenHouse, available at www.greenhousethinktank.org 
Warleigh-Lack, A and Van Langenhove, L (2010): 'Rethinking EU Studies: The Contribution of Comparative Regionalism', Journal of European Integration 32:6, 2010, 541-62.

Warleigh-Lack, A, Robinson, N and Rosamond, B (eds) (2011): European Studies and the New Regionalisms: Comparisons, Dialogues and New Research Directions London: Routledge

WCED (World Commission on Environment and Development, AKA the Brundtland Commission) (1987): Our Common Future. Oxford: Oxford University Press

Wendt, A and Duvall, R (2008): 'Sovereignty and the UFO', Political Theory 36:4, $607-33$

Wiener, A and Diez, T (2009): ‘Taking Stock of Integration Theory', in A Wiener and T Diez (eds) European Integration Theory Oxford: Oxford University Press, pp 241 52

Woodin, M. \&Lucas, C. (2004): Green Alternatives to Globalisation: A Manifesto London: Pluto

Wurzel, R and Connelly, J (eds) (2011): The European Union as a Leader in International Climate Change Politics London: Routledge 
Table 1: Arne Næss' Principles of Deep Ecology

\begin{tabular}{|l|}
\hline 1. All life on Earth has inherent value, regardless of its perceived usefulness \\
for humans; \\
\hline 2. Biodiversity contributes to human and non-human flourishing; \\
3. Humans must only reduce biodiversity in extremis and to satisfy vital \\
\hline 4. Humans currently interfere too much with the natural world; \\
\hline 5. Human population levels must decrease to allow for human and non- \\
human flourishing in the long term; \\
6. Basic economic, technological and ideological structures must be changed \\
if humans are to improve their life conditions; \\
7. This requires us to value quality of life, not standard of living; \\
\hline and economic change.
\end{tabular}

Source: adapted from Næss 1989: 29 
Table 2: Key Issues list

\begin{tabular}{|c|c|c|}
\hline ISSUE & SOURCE & $\begin{array}{l}\text { IMPLICATION FOR } \\
\text { INTEGRATION THEORY }\end{array}$ \\
\hline $\begin{array}{l}\text { Fighting climate change and } \\
\text { other ecological problems as } \\
\text { top priority }\end{array}$ & $\begin{array}{l}\text { Gaia theory (Lovelock } \\
\text { 2009); Shiva } 2005\end{array}$ & $\begin{array}{l}\text { Needs to become engaged, not } \\
\text { 'neutral' }\end{array}$ \\
\hline $\begin{array}{l}\text { Identity - recasting the } \\
\text { human as part of the Earth } \\
\text { system }\end{array}$ & $\begin{array}{l}\text { Gaia Theory; Deep } \\
\text { Ecology (Naess 1989) }\end{array}$ & $\begin{array}{l}\text { Rejection of anthropocentrism, and } \\
\text { imposition of duties towards the rest } \\
\text { of our co-inhabitants of the planet }\end{array}$ \\
\hline $\begin{array}{l}\text { Inherent value of all parts of } \\
\text { the planetary system - } \\
\text { animate or otherwise }\end{array}$ & $\begin{array}{l}\text { Gaia Theory; Deep } \\
\text { Ecology (Naess 1989); } \\
\text { Eckersley } 2004\end{array}$ & $\begin{array}{l}\text { Long-term perspective needed; } \\
\text { taking account of the needs of the } \\
\text { planet and the future }\end{array}$ \\
\hline $\begin{array}{l}\text { Symbiosis, not competition, } \\
\text { as the basis of existence }\end{array}$ & $\begin{array}{l}\text { Gaia Theory (Margulis } \\
\text { 1998; Litfin 2004); } \\
\text { Eckersley } 2004\end{array}$ & $\begin{array}{l}\text { Focus on struggle for social justice, } \\
\text { sharing the burden and resources } \\
\text { across the planet/region }\end{array}$ \\
\hline $\begin{array}{l}\text { Cosmopolitan perspectives } \\
\text { necessary }\end{array}$ & $\begin{array}{l}\text { Gaia Theory (Litfin 2004; } \\
\text { Madron and Jopling 2003); } \\
\text { Ecologism (Eckersley } \\
\text { 2004; Drengson and Devall } \\
\text { 2008) }\end{array}$ & $\begin{array}{l}\text { Challenging Westphalian } \\
\text { sovereignty, normatively and } \\
\text { practically, to fit scale of problems } \\
\text { and necessary solutions; } \\
\text { subsidiarity; network/multi-tier } \\
\text { governance }\end{array}$ \\
\hline $\begin{array}{l}\text { Democracy through } \\
\text { participation and inter- } \\
\text { generational justice }\end{array}$ & $\begin{array}{l}\text { Gaia Theory (Madron and } \\
\text { Jopling 2003); Deep } \\
\text { Ecology (Naess 1989); } \\
\text { Eckersley } 2004\end{array}$ & $\begin{array}{l}\text { Normative turn must be deepened } \\
\text { and greened }\end{array}$ \\
\hline $\begin{array}{l}\text { Epistemology based on } \\
\text { holism, symbiosis }\end{array}$ & $\begin{array}{l}\text { Gaia Theory; 'Ecology of } \\
\text { mind' }\end{array}$ & $\begin{array}{l}\text { Turn towards systems approaches } \\
\text { and interdisciplinarity }\end{array}$ \\
\hline $\begin{array}{l}\text { Reducing consumption; } \\
\text { rejecting neoliberalism }\end{array}$ & $\begin{array}{l}\text { Deep Ecology (Naess } \\
\text { 1989); Green political } \\
\text { economy (John 2012; Cato } \\
\text { 2009, 2013; Jackson 2009) }\end{array}$ & $\begin{array}{l}\text { Critique of both neoliberalism and } \\
\text { Keynesianism; re-thinking economic } \\
\text { integration as part of a nested, self- } \\
\text { reliant bioregional system }\end{array}$ \\
\hline
\end{tabular}


